\title{
NEW MATERIAL OF SIVAONYX BATHYGNATHUS (LUTRINAE, MUSTELIDAE) FROM THE EARLY PLIOCENE OF SIWALIKS, PAKISTAN
}

\author{
ABDUL GHAFFAR \\ Meteorology Department, COMSATS Institute of Information technology (CIIT), Islamabad, 44000, Pakistan. \\ aghaffar@comsats.edu.pk \\ MUHAMMAD AKHTAR \\ Department of Zoology, Quaid-i-Azam Campus, University of the Punjab, Lahore, 54000, Pakistan. \\ drakhtarfdrc@hotmail.com
}

\begin{abstract}
Seven species of Sivaonyx genus have been described so far from Eurasia and Africa. The type species of the genus is Sivaonyx bathygnathus (Lydekker), of which the holotype specimen is GSI D33. In this paper, new fragmentary material from the Dhok Pathan Formation (Middle Siwaliks) of Hasnot, Pakistan is described. Among the known late Miocene-Pliocene fossiliferrous localities, Hasnot is the only fossil bearing locality that preserves a significant fossil record of the genus Sivaonyx. Phylogenetic relationships and stratigraphic implications of the newly discovered material with already described specimens from the Siwaliks as well as with all known species of Sivaonyx from Africa and Asia are given. The new description of the specimen from the early Pliocene (5.3$3.5 \mathrm{Ma}$ ) show a younger stratigraphic range than described earlier in the Siwalik continental deposits.
\end{abstract}

Key words: Sivaonyx bathygnathus, fossil material, Hasnot, Dhok Pathan Formation, phylogenetic relationships.

\section{INTRODUCTION}

The right mandible fragment with $\mathrm{p} 4-\mathrm{m} 1$ of Sivaonyx bathygnathus (Lydekker, 1884) was collected from the Dhok Pathan Formation, near Hasnot village by the team of palaeontologists during the winter season of 2003. This record is significant because Mio-Pliocene carnivores are poorly represented in the Siwalik continental deposits. The new fossil of S. bathygnathus from Hasnot is thus an important addition for taxonomic as well as stratigraphic correlations. Hasnot village (32 $\left.49^{\prime} 27.89 \mathrm{~N} / 73^{\circ} 07^{\prime} 52.68 \mathrm{E}\right)$ is situated in northern Pakistan, approximately 54 km west of Jhelum city (Figure 1). This area has yielded one of the most taxonomically diverse carnivore faunas of late Miocene-early Pliocene age. At least, 19 genera in eight families of carnivores are recognized from this area including large and small carnivores (Ghaffar, 2005). Worldwide the subfamily Lutrinae (family Mustelidae) is represented by nine genera and 13 species. In the Siwalik continental deposits, Sivaonyx is represented by two species; S. bathygnathus and S. gandakasensis Pickford, 2007 (Grohé et al., 2013). These bunodont otters successfully occupied the continental ecosystems of Europe, Asia, Africa and North America. Similarly, family Mustelidae is the most diverse family of carnivores with more than 60 extant species (Wilson \& Reeder, 1993). Late Miocene otters from the Dhok Pathan Formation of the Siwaliks have been described by various authors (Lydekker, 1884; Pilgrim, 1931; Brown, 1926; Matthew, 1929; Colbert, 1935; Pickford, 2007). All the described specimens including the type specimen and the specimen under study were collected from the Hasnot area. Similarly on the basis of similarities to the type specimen (GSI D33) of S. bathygnathus from the Siwaliks, other species of this genus have been described from the Miocene-Pleistocene deposits of North America, Europe and Africa (Repenning, 1976; Alcalá, 1994; Hürzeler, 1987; Pilgrim, 1931; Villalta \& Crusafont-Pairó, 1945; Willemsen, 1992, 1999; Hendey, 1974; Morales et al., 2005; Morales \& Pickford, 2005a,b; Pickford, 2007; Petter et al., 1991; Stromer, 1931; Werdelin, 2003; Bonis et al., 2008; Peigné et al., 2008; Grohé et al., 2013).

All the Siwalik formations (i.e. Kamlial, Chinji, Nagri, Dhok Pathan and Soan Formation) are well exposed in the Hasnot area surrounded by extensive Neogene freshwater sedimentary rocks. Like the Dhok Pathan type locality, the Hasnot is another famous fossil-bearing site in the Siwalik continental deposits (Lydekker, 1884; Pilgrim, 1910, 1913, 1932; Matthew, 1929; Colbert, 1935; Pilbeam et al., 1977; De Vos et al., 1987; Barry \& Flynn, 1989; Behrensmeyer et al., 1995; Barry et al., 2002; Khan et al., 2009; Ghaffar et al., 2010). This fossil region contains lateral facies associations within the fine-grained fossilbearing floodplain deposits that are characteristic of fluvial depositional environments (Barry \& Flynn, 1989; Wills \& Behrensmeyer, 1995; Behrensmeyer et al., 1995; Barry et al., 2002). Based on the lithological characteristics, the study area belongs to the upper Dhok Pathan Formation (Middle Siwaliks), which is characterized by sandstones with alternate clays that are orange brown in color, scattered conglomerates in the lower part, and conglomerate with sandstone and clays in the upper part (Pilbeam et al., 1977; Cheema et al., 1977; Johnson et al., 1982; Barry et al., 1982). The fossil assemblages (i.e. hipparionines, artiodactyls and carnivores) collected from the study area 


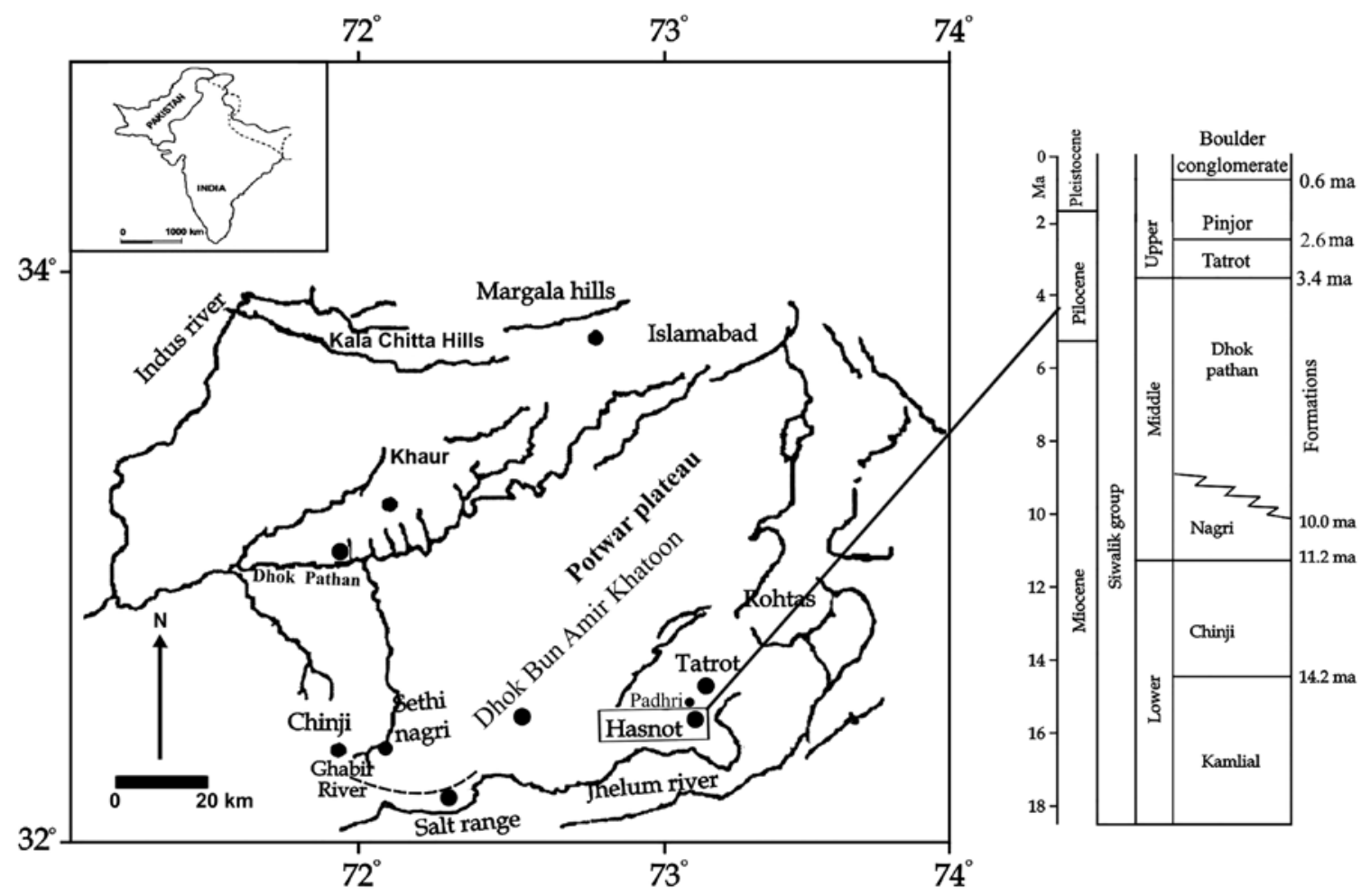

Figure 1. Map of Potwar Plateau (northern Pakistan) with fossil site and stratigraphic section of the major Siwalik formations (modified from Behrensmeyer \& Barry, 2005; boundary dates are from Barry et al., 2002).

suggest that the age of the fossil site is latest Miocene-early Pliocene (Colbert, 1935; Barry et al., 2002; Khan et al., 2009; Ghaffar et al., 2010).

The aim of this paper is to describe the mustelid fauna from the Siwalik continental deposits. The taxonomy and even the diversity of these bunodont otters has been the subject of much debate based on the fragmentary nature of their fossil record. The fossil record of Siwalik mustelids is based on the fragmentary mandibles, maxillary portions and even isolated upper and lower teeth. Due to this fragmentary nature of the fossil record, assignment of different species to different genera are controversial; this is particularly the case with Sivaonyx and Enhydriodon. The recovery of new fossil material provides an opportunity to reassess the stratigraphic implications as well the taxonomic assignments of fossil otters from the Pliocene sediments of Hasnot, Pakistan.

\section{MATERIAL AND METHODS}

The described specimen was collected from the area around Hasnot village (Dhok Pathan Formation), Punjab, Pakistan and is housed in the collections of the Abu Bakr Fossil Display and Research Centre, University of the Punjab, Lahore, Pakistan. Measurements were taken in millimeters with metric vernier calipers. Comparisons were made with the different species of Sivaonyx, available from Asia, Africa and Europe (Table 1). The specimen is catalogued by giving a number that consists of the year of collection followed by a serial catalogue number (e.g. $2003 / 15)$. Upper case letters stand for upper teeth and lower case letters stand for lower teeth. The morphological and metrical characters of the specimen are described and its systematic determination is discussed in detail.

Abbreviations: AMNH, American Museum of Natural History, New York, USA; BAR, fossils from Baringo District, Community Museums of Kenya; BMNH, British Museum of Natural History, London, United Kingdon; BSPG, Bayerische Staatssammlung für Paläontologie und historische Geologie, Munich, Germany; GSI, Geological survey of India; GSP-Y, Yale University-Geological Survey of Pakistan; IVPP V, Institute of Vertebrate Paleontology and Paleoanthropology, Beijing, Vertebrate collection; KNM, Kenya National Museum, Nairobi; NK, fossils from Nkondo, Uganda National Museum, Kampala; PUPC, Punjab University Palaeontological Collection; SAM PQ-L, Iziko South African Museum, Cape Town; TM, fossils from Toros-Menalla, Chad; YPM, Yale Peabody Museum, S, Sivaonyx, p4, fourth lower premolar, $\mathbf{m 1}$, first lower molar.

\section{SYSTEMATIC PALAEONTOLOGY}

Order CARNIVORA Bowdich, 1821

Suborder CANIFORMIA Kretzoi, 1943

Family MUSTELIDAE Fischer, 1817

Subfamily LUTRINAE Bonaparte, 1838

Sivaonyx Pilgrim, 1931

Type species. Sivaonyx bathygnathus Lydekker, 1884. 
Table 1. Lower dental measurements (in mm) of different Sivaonyx species. Measurements are taken from Pilgrim (1932), Colbert (1935) Qi (1983), Zong (1997), Werdelin (2003), Morales et al. (2005), Morales \& Pickford (2005a,b), Pickford (2007), Peigné et al. (2008), Grohé et al. (2013).

\begin{tabular}{|c|c|c|c|}
\hline Species \& Specimen No. & Position & Length & Width \\
\hline Sivaonyx bathygnathus (PUPC 2003/15) & $\mathrm{p} 4$ & 7.5 & 5.5 \\
\hline Studied material & $\mathrm{m} 1$ & 16 & 9.5 \\
\hline S. bathygnathus GSI D 33 (holotype) & $\mathrm{m} 1$ & 17.1 & 9.7 \\
\hline GSI D 156 & $\mathrm{~m} 1$ & 16 & 9.4 \\
\hline GSI D 250 & $\mathrm{~m} 1$ & 16.4 & 9.1 \\
\hline AM 19509 & $\mathrm{~m} 1$ & 16.5 & 9.5 \\
\hline IVPP V 6886.12 & $\mathrm{~m} 1$ & 15.9 & 9 \\
\hline S. cf. bathygnathus (YV 2517) & $\mathrm{m} 1$ & 14 & 8 \\
\hline S. gandakasensis GSP-Y 4225 (holotype) & $\mathrm{m} 1$ & 15 & 7.9 \\
\hline GSP-Y 11703 & $\mathrm{~m} 1$ & 13.9 & 7.9 \\
\hline GSI D 249 & $\mathrm{~m} 1$ & 14.4 & 8.6 \\
\hline BMNH M 13175 & $\mathrm{~m} 1$ & 15.4 & 9.1 \\
\hline S. gandakasensis BMNH G 4 & $\mathrm{~m} 1$ & 12.8 & 7.6 \\
\hline Sivaonyx cf. gandakasensis CM-03-A & $\mathrm{m} 1$ & 13.7 & 7.6 \\
\hline YPM 20206 & $\mathrm{~m} 1$ & 15.4 & 8.5 \\
\hline S. hessicus BMNH 27486 (holotype) & $\mathrm{m} 1$ & 15.9 & 8.6 \\
\hline S. beyi TM 171-01-033 (holotype) & $\mathrm{m} 1$ & 20.3 & \\
\hline TM 172-05-0019 & $\mathrm{m} 1$ & 22.8 & 13.4 \\
\hline TM 355-02-0029 & $\mathrm{m} 1$ & 20 & 11.6 \\
\hline TM 247-01-0059 & $\mathrm{m} 1$ & 21.5 & 12.7 \\
\hline S. ekecaman KNM-KP 10034 (holotype) & $\mathrm{m} 1$ & 21.2 & 13.5 \\
\hline BAR 720’03 & $\mathrm{m} 1$ & & 12.8 \\
\hline BAR 567’05 & $\mathrm{m} 1$ & 20.1 & 13 \\
\hline S. soriae KNM-LU 337 \& 338 (holotype) & $\mathrm{m} 1$ & 17.6 & 10.5 \\
\hline BAR 1984’05 & $\mathrm{m} 1$ & 17.5 & 10.6 \\
\hline S. hendeyi SAM PQ-L 5000 (holotype) & $\mathrm{m} 1$ & 21.3 & 13.1 \\
\hline S. kamuhangirei Unnumbered (holotype) & $\mathrm{m} 1$ & 26 & 15.9 \\
\hline NK 1988’89 & $\mathrm{m} 1$ & & 14.4 \\
\hline S. africanus BSPG 1930 XI 1 (holotype) & $\mathrm{m} 1$ & 22.2 & \\
\hline
\end{tabular}

Other species. Sivaonyx africanus (Stromer, 1931), Sivaonyx hendeyi (Morales et al., 2005), Sivaonyx ekecaman (Werdelin, 2003), Sivaonyx kamuhangirei (Morales \& Pickford, 2005a), Sivaonyx hessicus (Lydekker, 1890), Sivaonyx beyi (Peigné et al., 2008), Sivaonyx gandakasensis (Pickford, 2007) Sivaonyx soriae (Morales \& Pickford, 2005b), Sivaonyx senutae (Morales \& Pickford, 2005b).

Distribution. Middle-late Miocene of Asia (India, Pakistan, Thailand, China), late Miocene of Europe (Germany, Turkey). Late Miocene-early Pleistocene of Africa (Egypt, Chad, Ethiopia, Kenya, Uganda, South Africa).

Sivaonyx bathygnathus Lydekker, 1884

(Figure 2)
Studied material. PUPC 2003/15, fragmentary right mandible lacking the incisors and $\mathrm{m} 2$ and includes $\mathrm{p} 4-\mathrm{m} 1$ and the roots of $\mathrm{p} 3$.

Diagnosis. Lutrinae of large size; having a P4 of an approximately quadrate shape with a moderately trenchant paracone-metacone blade; paracone somewhat stoutly built; metacone very slightly elongate; parastyle well developed but low; with two internal cusps, protocone and hypocone, lower than the outer cusps, somewhat swollen and expanded so that the basin-shaped area is contracted; with a strong internal cingulum; mandible with a ramus deeper than the length of $\mathrm{m} 1$; canine large; $\mathrm{p} 1$ single rooted; $\mathrm{p} 4$ broad posteriorly, with a strong, outwardly situated posterior cusp and a broad cingulum, no anterior accessory cusp; $\mathrm{m} 1$ very 

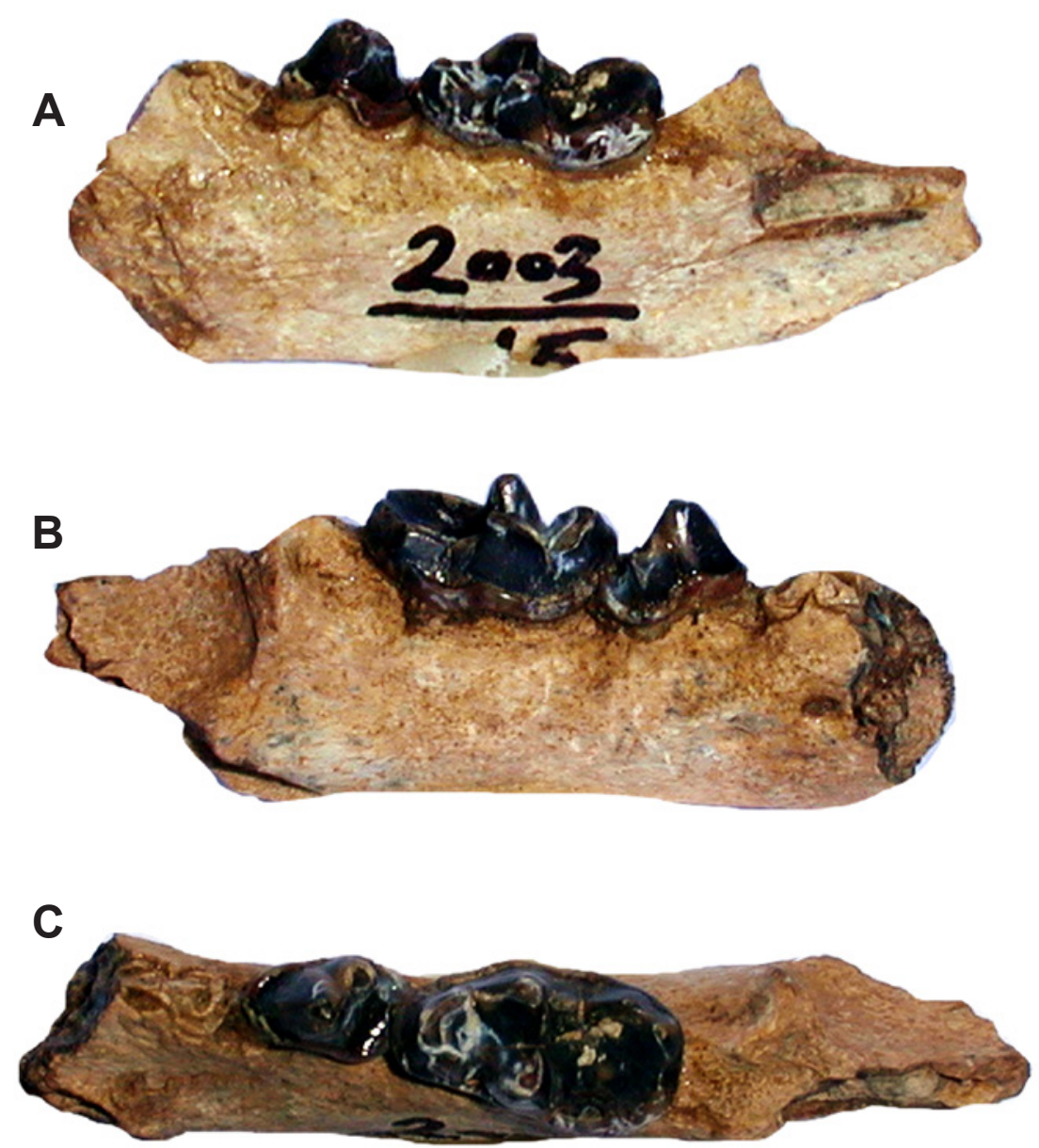

Figure 2. Sivaonyx bathygnathus, PUPC 2003/15. A, lingual; B, buccal and C, occlusal views. Scale bar $=10 \mathrm{~mm}$.

broad; paraconid situated so as to be bisected by the median axis of the tooth; metaconid as high as paraconid; talonid broader than trigonid and approximately equal in length to it, basin-shaped, surrounded by a ring of cusps of which the entoconid is as well developed as the hypoconid; $\mathrm{m} 2$ small, oval (Pilgrim, 1932; Grohé et al., 2013).

Description. PUPC 2003/15 is a fragmentary right mandible lacking the incisors and $\mathrm{m} 2$ and includes $\mathrm{p} 4-\mathrm{m} 1$ and the roots of $\mathrm{p} 3$. The preserved length of the mandibular ramus is 58.2 $\mathrm{mm}$. The maximum breadth of this ramus is $9.6 \mathrm{~mm}$. The depth of the ramus below $\mathrm{p} 3$ and $\mathrm{m} 1$ is $21 \mathrm{~mm}$ and $17.7 \mathrm{~mm}$, respectively. The preserved length of symphysis is $8.5 \mathrm{~mm}$. It is in an excellent state of preservation and the teeth are at medium wear. In p4 the main cusp (protoconid) is high with sharp anterior edge and the anterior cusp is absent while the posterior cusp (post-protocind cusplet) is well developed and prominent, particularly on the outer side of the tooth. In $\mathrm{m} 1$, the metaconid and protoconid are almost equal in size but both are higher than the paraconid. Moreover, the metaconid is more lingual than the paraconid. The protoconid and the paraconid are separated by a well-marked carnassial notch while a deep V-shaped valley separates the paraconid from the metaconid. The metaconid is displaced distally with respect to the protoconid and is curved backwardly in lingual view. A small cuspule is also present at the distal base of the protoconid. The talonid exhibits a tall hypoconid crest but lower than the paraconid, a weaker and curved entoconid crest, and a narrow and shallow talonid basin. Both p4 and $\mathrm{m} 1$ show finely wrinkled enamel (Figure 2). The symphysis is deep and short. There are two mental foramina, one beneath p3 and the other one beneath p4. The anterior one is slightly larger than the posterior one. The hollow space left by the canine is also well preserved, it is circular in its general outline and its diameter is $6 \mathrm{~mm}$.

\section{DISCUSSION}

This paper deals with the description of new material of Sivaonyx bathygnathus from the early Pliocene (Middle Siwaliks) of Hasnot. The holotype (GSI D 33) of this species (Sivaonyx bathygnathus) is a left mandible fragment with partial p4-m1, alveoli of canine (C) and p1-p3 illustrated by Lydekker (1884, pl. 27, fig. 3), and re-illustrated and figured by Pohle (1919, pl. 2, fig. 2) and Matthew (1929, 
fig. 8). Direct comparison of the morphological features of the studied material with the type specimen and with the additional materials described by Pilgrim (1932) and Colbert (1935) permits comparison with the lower carnassials from the Siwalik continental deposits. The type species S. bathygnathus has long been the only Sivaonyx species reported from Asia. This species was originally described from the late Miocene of the Siwalik Hills of Pakistan (Hasnot, Potwar Plateau; Lydekker, 1884; Pilgrim, 1931, 1932; Matthew, 1929, Colbert, 1935). Later on, the same species was reported in the late Miocene of Haritalyangar, India (Prasad, 1968, incorrect identification), Lufeng and possibly Yuanmou, Yunnan Province of China (Qi, 1979, 1983; Zong, 1997; Qi et al., 2006). The studied specimen was collected from the same vicinity (i.e. Hasnot; Dhok Pathan Formation; Middle Siwaliks) from where the Holotype specimen described by Lydekker (1884) was found. Although the origin and age of the type material is not precisely known, a literature review indicates that the described specimens of $S$. bathygnathus were collected from late Miocene-early Pliocene deposits and according to Pilgrim (1931) most possibly from the late Miocene sediments. The morphology of the studied specimen is similar to the type specimen as well as the additional specimens described by earlier workers (Lydekker, 1884; Pilgrim, 1931, 1932; Matthew, 1929; Colbert, 1935). The specimen under study differs from the holotype material (GSI D 33) as well as from GSI D 156 and AM 19509 by its smaller length and width dimensions of $\mathrm{m} 1$. According to Pickford (2007), S. gandakasensis is the oldest Sivaonyx species described from Kaulial, Nagri Formation, lower Middle Siwaliks of Pakistan. Moreover, the tooth dimensions of the studied material are greater than those of $S$. gandakasensis and $S$. hessica but are smaller than the other Eurasian and African species (see Table 1). Similarly, the studied specimen is different from $S$. gandakasensis as this species is recognized by the narrow and triangle-shaped trigonid, paraconid-protoconid blades forming a more opened angle, higher than the metaconid and a narrower talonid basin relative to the trigonid. In the studied specimen, the mandible ramus is deeper than the length of $\mathrm{m} 1, \mathrm{p} 4$ broad posteriorly, with a strong posterior cusp, situated outwardly, m1 broad, metaconid and paraconid are almost equal in height, talonid broader than the trigonid and approximately equal in length to it, talonid is basin-shaped, surrounded by a ring of cusps of which the entoconid is as well developed as the hypoconid. Pilgrim (1931) argued that there are strong morphological similarities of Sivaonyx species within the Europe and Subcontinent India. Later on Pickford (2007) agreed with Pilgrim's views and even suggested that the genus Sivaonyx occurred in Africa and Asia.

Affiliation of different species to Sivaonyx and Enhydriodon is still controversial due to fragmentary nature of fossil records of mustelids. The size difference between Enhydriodon and Sivaonyx is small and even the morphology of the lower carnassial (m1) is similar in both the genera. In general, bunodont teeth are referred to Enhydriodon while the sectorial dentition is referred to Sivaonyx, and the specimen under study show the sectorial dentition. In addition, in Sivaonyx, the cusplets encircles the entire tooth and usually found together to form two elongated cusps, as seen in the specimen under study, while in Enhydriodon cusplets around the margin of talonid tend to be discrete.

As stated above, apparently, the morphological differences in Sivaonyx and Enhydriodon are very small, but Enhydriodon has precedence over Sivaonyx and on this basis Werdelin \& Lewis (2013) considered that the African fauna belonged to Enhydriodon rather than to Sivaonyx. The fossil record of family Mustelidae is much better in Asia compared to Africa. At present, the taxonomy of Sivaonyx and Enhydriodon is under revision and it is very difficult to assign different species either to Sivaonyx or to Enhydriodon because the overlapping diagnostic characteristics make it difficult to assign different species to these two genera. Based on the above observation, we here attribute the new Hasnot material to Sivaonyx rather than to Enhydriodon as this paper deals with the lower dentition and the type material of Sivaonyx bathygnathus is similar to the material described in this paper. In addition to the above-mentioned points, additional observations regarding the studied specimen are here considered.

Werdelin \& Lewis (2013) included the African specimens in Enhydriodon, which they considered to be the senior synonmy over Sivaonyx, but the horizon mentioned for Enhydriodon sivalensis by Pilgrim (1931) is Upper Siwaliks while for Enhydriodon falconeri may be the Dhok Pathan age. Werdelin \& Lewis (2013) also mentioned that the specimens collected from Koobi Fora, assigned to different species of Enhydriodon are larger, with morphology distinct from Sivaonyx species (Sivaonyx beyi and Sivaonyx bathygnathus). Based on stratigraphic and biochronological context, we can argue that among the bunodont otters, Vishnuonyx chinjiensis has an older stratigraphical range (Lower Siwaliks) than Sivaonyx [S. bathygnathus and S. gandakaensis (Middle Siwaliks)]. Similarly, Sivaonyx has an older stratigraphic range than Enhydriodon [E. sivalensis and E. falconeri (upper Middle Siwaliks-Upper Siwaliks). For the stratigraphic implications, we rely on Pilgrim Zone's (1913) and our own field observations based on the associated faunas from the Hasnot region which accord with these Zones (Pilgrim Zones). The Zones defined by Pilgrim (1913) are broad but provide a general sense to the sequences of events. However, the fauna from different Pilgrim Zones is mostly in agreement with our new collections and findings. At this stage, with a very limited material, we can only suggest that smaller specimens of two genera (Sivaonyx and Enhydriodon) from the older stratigraphic range can be assigned to Sivaonyx while the large specimens from the younger stratigraphic range can be assigned to Enhydriodon. This fits well with the African (Koobi Fora) materials because most of these species are described from strata which are equivalent in age to the Upper Siwaliks. The increase in size over time within the Sivaonyx lineage cannot be assessed because the studied specimen has smaller anteroposterior dimensions than the type specimen and other specimens of the same species collected from late Miocene sediments. 
According to Pickford (2007), Sivaonyx (S. bathygnathus and $S$. gandakasensis) is intermediate between Vishnuonyx (V. chinjiensis) and Enhydriodon (E. sivalensis and E. falconeri). At the end of the Miocene, the molluscivorous lineage Enhydriodon evolved and then persisted until the end of the Pliocene. In Africa, Sivaonyx increased in body size and developed extremely bunodont dentition. According to Werdelin \& Lewis (2013), this statement is consistent with the data available from Koobi Fora, Africa. At the generic level, the increase in size over time might be persistent within these three genera (Vishnuonyx, Sivaonyx, Enhydriodon) as argued by Morales \& Pickford (2005a,b). The morphological modification can be justified as the specimens described from the younger stratigraphic range of Koobi Fora, Africa, may be more bunodont compared to the more sectorial dentition mentioned by Werdelin \& Lewis (2013). Werdelin \& Lewis (2013) also mentioned this blunt characteristic for the newly described species E. ekecaman (Early Pliocene age; 3.583.44 Ma). By summarizing the above statements, we can only comment that there is a morphological modification from sectorial dentition to bunodont dentition within these genera. Sivaonyx gandakasensis from Gandakas (Nagri Formation), Pakistan, is the oldest representative of the genus Sivaonyx from Siwalik continental deposits of Pakistan. Similarly, the fossil remains of this species from northern Thailand (12.4-12.2 Ma) are the oldest known remains of this genus from Asia (Grohé et al., 2013). Subsequently, Sivaonyx beyi from the Late Miocene of Toros-Menalla, Chad, is the oldest representative of this genus from Africa (Peigné et al., 2008).

The stratigraphic analyses of the fossil site indicate that the specimen under study is from the younger Dhok Pathan Formation (early Pliocene) as the additional fauna, particularly the Cervidae fossils collected from the area (Hasnot), confirms the Ruscinian age (equivalent to MN14; early Pliocene), because the earliest record of different species of tribe Cervini in the Siwaliks is not older than the early Pliocene (Barry et al., 2002; Khan et al., 2009; Ghaffar et al., 2010; Ghaffar \& Akhtar, 2012). According to mitochondrial DNA analysis, the Muntiacinae-Cervinae split occurred at Miocene/Pliocene transition (Pitra et al., 2004) and this is in agreement with the early Pliocene fossil record of family Cervidae from the Siwaliks continental deposits.

The studied specimen is somewhat smaller than the type specimen. Although the stratigraphic range of the type specimen (D 33) is not clear, it may be assumed from the literature that it is from the Dhok Pathan Formation (late Miocene). From the area around Hasnot, the fossils occur in pockets and all the component formations, i.e. Kamilial, Chinji, Nagri, Dhok Pathan and Soan Formation, are well exposed in the vicinity of Hasnot area (Ghaffar, 2005; Khan et al., 2009). The exact fossil site from which the mandible was collected is $2.5 \mathrm{Km}$ on the SW side of Hasnot village towards the Kotal Kund across the Bunnah river. The fossil site represents the upper Dhok Pathan Formation (early Pliocene). Cheema et al. (1977) described the Dhok Pathan Formation as being typically represented by monotonous cyclic alternations of sandstone and clay beds. Conglomerate in the form of lenses and a layer is an essential character of the upper part of Dhok Pathan Formation. The thickness of one sandstone-clay cycle varies from 6-60 m. The diversified rich mammalian fauna from the fossil site is also indicative of a Pliocene age (Shah, 2009). According to extensive field surveys from 1998-onward, particularly in the Dhok Pathan type locality as well as at Hasnot, we observed that the latest Miocene-Pliocene strata (Upper Dhok Pathan Formation; 6-3.5 Ma) are richer in faunal assemblages compared to late Miocene deposits (Early-Middle Dhok Pathan Formation; 10.1-6 Ma). Based on Cervidae fossil remains, we can argue that the different localities in the study area (around Hasnot village) belongs to Upper Dhok Pathan Formation (Pliocene) in addition to late Miocene sediments (Early-Middle Dhok Pathan Formation).

\section{ACKNOWLEDGMENTS}

The authors want to thank to L. Werdelin for the preliminary identification and kindly providing the literature regarding this paper. The first author is also grateful to R.M. Ibrahim and his team (COMSATS Library Information Services) for their efforts to provide the necessary literature for this study. Moreover, we would like to thank the reviewers for their corrections and constructive remarks to improve this manuscript. This research is supported by Higher Education Commission, Pakistan (grant No. 20-2234/R \& D/11) to Abdul Ghaffar under National Research Program for Universities (NRPU) to study Pliocene Mammalian Fauna from the Siwaliks of Pakistan.

\section{REFERENCES}

Alcalá, L. 1994. Macromammiferos neogenos de la Fosa de Alfambra-Teruel. Madrid, Museo Nacional de Ciencias Naturales, 554 p.

Barry, J.C. \& Flynn, L.J. 1989. Key biostratigraphic events in the Siwalik sequence. In: E.H. Lindsay; V. Fahlbusch \& P. Mein (eds.) European Neogene mammal chronology, Plenum Press, p. 557-571. doi:10.1007/978-1-4899-2513-8_33

Barry, J.C.; Lindsay, E.H. \& Jacobs, L.L. 1982. A biostratigraphic zonation of the Middle and Upper Siwaliks of the Potwar Plateau of northern Pakistan. Palaeogeography, Palaeoclimatology, Palaeoecology, 37:95-130. doi:10.1016/0031-0182(82)90059-1

Barry, J.C.; Morgan, M.; Flynn, L.J.; Pilbeam, D.; Behrensmeyer, A.K.; Raza, S.M.; Khan, I.; Badgely, C.; Hicks, J. \& Kelley, J. 2002. Faunal and environmental change in the Late Miocene Siwaliks of Northern Pakistan. Palaeobiology, 28:1-71. doi:10.1666/0094-8373(2002)28[1:faecit]2.0.co;2

Behrensmeyer, A.K. \& Barry, J.C. 2005. Biostratigraphic surveys in the Siwaliks of Pakistan: A method for standardized surface sampling of the vertebrate fossil record. Palaeontologia Electronica, 8:15A.

Behrensmeyer, A.K.; Wills, B.J. \& Quade, J. 1995. Floodplains and paleosols of Pakistan Neogene and Wyoming Paleogene deposits: a comparative study. Palaeogeography, Palaeoclimatology, Palaeoecology, 115:37-60. doi:10.1016/0031-0182(94)00106-i 
Bonis, L.de.; Peigné, S.; Mackaye, H.T.; Likius, A.; Vignaud, P. \& Brunet, M. 2008. The fossil vertebrate locality Kossom Bougoudi, Djurab desert, Chad: a window in the distribution of the carnivoran faunas at the Mio-Pliocene boundary in Africa. Comptes Rendus Palevol, 7:571-581. doi:10.1016/j. crpv.2008.10.004

Brown, B. 1926. A new deer from the Siwaliks. American Museum Novitates, 242:1-6.

Cheema, M.R.; Raza, S.M. \& Ahmad, H. 1977. Cainozoic. In: S.M.I. Shah (ed.) Stratigraphy of Pakistan, Quetta, Geological Survey of Pakistan, p. 56-98 (Memoirs 12).

Colbert, E.H. 1935. Siwalik Mammals in the American Museum of Natural History. Transactions of the American Philosophical Society, New Series, 26:1-401. doi:10.2307/1005467

De Vos, J.; Leinders, J.J.M. \& Hussain, S.T. 1987. A historical review of the Siwalik Hyaenidae (Mammalia, Carnivora) and description of two new finds from the Upper Siwalik of Pakistan. Proceedings of the Koninklijke Nederlandse Akademie van Wetenschappen B, 90:333-369.

Ghaffar, A. 2005. Studies on equids, cervids and Carnivora from the Siwalik Hills of Pakistan. University of the Punjab, Ph.D. thesis, $389 \mathrm{p}$.

Ghaffar, A. \& Akhtar, M. 2012. New fossil record of Hyaenictitherium pilgrimi (Carnivora: Hyaenidae) from Dhok Pathan Formation of Hasnot, Pakistan. Swiss Journal of Paleontology, 131:275-281. doi:10.1007/s13358-012-0042-y

Ghaffar, A.; Khan, M.A. \& Akhtar, M. 2010. Early Pliocene Cervids (Artiodactyla-Mammalia) from the Siwaliks of Pakistan. Yerbilimleri, 31:217-231.

Grohé, C.; de Bonis, L.; Chaimanee, Y.; Blondel, C. \& Jaeger, J.J. 2013. The oldest Asian Sivaonyx (Lutrinae, Mustelidae): a contribution to the evolutionary history of bunodont otters. Palaeontologia Electronica, 16:29A.

Hendey, Q.B. 1974. The late Cenozoic Carnivora of the southwestern Cape Province. Annals of the South African Museum, 63:1-369.

Hürzeler, J. 1987. Die Lutrinen (Carnivora, Mammalia) aus dem "Grosseto-Lignit" der Toscana. Schweitzer. Paläontologische Abhandlungen, 110:28-48.

Johnson, N.M.; Opdyke, N.D.; Johnson, G.D.; Lindsay, E.H. \& Tahirkheli, R.A.K. 1982. Magnetic polarity stratigraphy and ages of Siwalik Group rocks of the Potwar Plateau, Pakistan. Palaeogeography, Palaeoclimatology, Palaeoecology, 37:17-42. doi:10.1016/0031-0182(82)90056-6

Khan, M.A.; Iliopoulos, G. \& Akhtar, M. 2009. Boselaphines (Artiodactyla, Ruminantia, Bovidae) from the Middle Siwaliks of Hasnot, Pakistan. Geobios, 42:739-753. doi:10.1016/j. geobios.2009.04.003

Lydekker, R. 1884. Rodents and new ruminants from the Siwalik and synopsis of Mammalia. Palaeontologica Indica, 10:1-5. doi:10.1080/00222938509487507

Matthew, W.D. 1929. Critical observations upon Siwalik mammals. Bulletin of the American Museum of Natural History, 56:437-560.

Morales, J. \& Pickford, M. 2005a. Giant bunodont Lutrinae from the Mio-Pliocene of Kenya and Uganda. Estudios Geologicos, 61:233-246. doi:10.3989/egeol.05613-666

Morales, J. \& Pickford, M. 2005b. Carnivores from the Middle Miocene Ngorora Formation (13-12 Ma) Kenya. Estudios Geologicos, 61:271-284. doi:10.3989/egeol.05613-668

Morales, J.; Pickford, M. \& Soria, D. 2005. Carnivores from the late Miocene and basal Pliocene of the Tugen Hills, Kenya. Revista de la Sociedad Geologica de Espana, 18:39-61.
Peigné, S.; de Bonis, L.; Likius, A.; Mackaye, H.T.; Vignaud, P. \& Brunet, M. 2008. Late Miocene Carnivora from Chad: Lutrinae (Mustelidae). Zoological Journal of the Linnean Society, 152:793-846. doi:10.1111/j.1096-3642.2008.00377.x

Petter, G.; Pickford, M. \& Howell, F.C. 1991. La loutre piscivore du Pliocène de Nyaburogo et de Nkondo (Ouganda, Afrique orientale): Torolutra ougandensis n.g., n.sp. (Mammalia, Carnivora). Comptes Rendus de l'Académie des Sciences, série 2, 312:949-955.

Pilbeam, D.; Barry, J.; Meyer, G.E.; Shah, S.M.I.; Pickford, M.H.L.; Bishop, W.W.; Thomas, H. \& Jacobs, L.L. 1977. Geology and palaeontology of Neogene strata of Pakistan. Nature, 270:684689. doi:10.1038/270684a0

Pickford, M. 2007. Revision of the Mio-Pliocene bunodont otterlike mammals of the Indian Subcontinent. Estudios Geologicos, 63:83-127. doi:10.3989/egeol.07631192

Pilgrim, G.E. 1910. Notices of new Mammalian genera and species from the Tertieries of India-Calcutta. Records of Geological Survey of India, 40:63-71.

Pilgrim, G.E. 1913. Correlation of the Siwaliks with mammal horizons of Europe. Records of Geological Survey of India, 43: $264-326$.

Pilgrim, G.E. 1931. Catalogue of the Pontian Carnivora of Europe in the Department of Geology. London, British Museum of Natural History, $174 \mathrm{p}$.

Pilgrim, G.E. 1932. The fossil Carnivora of India. Palaeontologia Indica, 18:1-232. doi:10.1017/s0016756800096448

Pitra, C.; Fickela, J.; Meijaard, E. \& Groves, C.P. 2004. Evolution and phylogeny of old world deer. Molecular Phylogenetics and Evolution, 33:880-895. doi:10.1016/j.ympev.2004.07.013

Pohle, H. 1919. Die unterfamilie der Lutrinae. Archiv for Naturgeschichte, 85:1-247. doi:10.2307/1373608

Prasad, K.N. 1968. The vertebrate fauna from the Siwalik beds of Haritalyangar, Himachal Pradesh, India. Paleontologia Indica, 39:1-55.

Qi, G. 1979. Pliocene mammalian fauna of Lufeng, China. Vertebrata PalAsiatica, 17:14-22.

Qi, G. 1983. Description of Carnivora fossils from Lufeng. Acta Anthropologica Sinica, 2:11-20.

Qi, G.; Dong, W.; Zheng, L.; Zhao, L.; Gao, F.; Yue, L. \& Zhang, Y. 2006. Taxonomy, age and environment status of the Yuanmou hominoids. Chinese Science Bulletin, 51:704-712. doi:10.1007/ s11434-006-0704-5

Repenning, C. A. 1976. Enhydra and Enhydriodon from the Pacific Coast of North America. Journal of Research of the U.S. Geological Survey, 4:305-315.

Shah, S.M.I. 2009. Stratigraphy of Pakistan. Geological Survey Pakistan Memoirs, 22:1-381.

Stromer, E. 1931. Reste Süsswasser und Land bewohnender Wirbeltiere aus den Diamantfeldern Klein-Namaqualandes (Südwest Afrika). Sitzungsberichte der Bayerischen Akademie der Wissenschaften, 1:17-47.

Villalta, J.F. \& Crusafont-Pairó, M. 1945. Enhydriodon lluecai n. sp. el primer lútrido del Pontiense español. Boletin de la Real Sociedad Española de Historia Natural, 43:383-396.

Werdelin, L. 2003. Mio-Pliocene Carnivora from Lothagam, Kenya. In: M.G. Leakey \& J.M. Harris (eds.) Lothagam: The Dawn of Humanity in Eastern Africa, Columbia University Press, p. 261330. doi:10.5860/choice.41-0949

Werdelin, L. \& Lewis, M.E. 2013. Mio-Pliocene Carnivora (Family Mustelidae) from Koobi Fora, Africa. California Academy of Sciences, 7:31-72. 
Willemsen, G.F. 1992. A revision of the Pliocene and Quaternary Lutrinae from Europe. Scripta Geologica, 101:1-115.

Willemsen, G.F. 1999. Some remarks on the Enhydrini (Lutrinae) from the Siwaliks, Pakistan. Deinsea, 7:411-418.

Wills, B.J. \& Behrensmeyer, A.K. 1995. Fluvial systems in the Siwalik Neogene and Wyoming Paleogene. Palaeogeography, Palaeoclimatology, Palaeoecology, 115:1335. doi:10.1016/0031-0182(94)00105-h
Zong, G. 1997. Carnivora. In: Z.-q. He (ed.) Yunamou Hominoid Fauna, Yunnan Science and Technology Press, p. 69-89.

Received in November, 2015; accepted in February, 2016. 

